
www.globaljournalseries.com, Email: info@globaljournalseries.com

\title{
FOOD AND NUTRIENT INTAKE OF PREGNANT WOMEN OF THE OUT PATIENT DEPARTMENT OF GENERAL HOSPITAL, CALABAR, NIGERIA
}

\section{GRACE MICHAEL INAH, MARY IYAM AND MGBAN, EMILIA}

(Received 15 June 2012; Revision Accepted 17 October 2012)

\begin{abstract}
This study investigated nutrient intake and the prevalence of nutrient inadequacy among pregnant women who attended antenatal clinic in General Hospital Calabar, Cross River State, Nigeria, and assess factors associated with nutrient inadequacy. Pregnant women who attended prenatal clinic in general Hospital Calabar, Nigeria was surveyed. Nutrient intake was estimated based on information provided by the women on the amount, type and frequency of various foods eaten. The survey showed that $33 \%$ of the respondents were under weight, $55.3 \%$ had normal BMI and $41.3 \%$ of the pregnant women were overweight. The respondents who prefer rice and noodles were $44 \%, 84 \%$ of the respondents like hot food, $12.0 \%$ like cold food, while $4.0 \%$ like both hot and cold food and $71 \%$ of them had no food preference. The respondents met $41.9 \%$ of Recommended Dietary Allowance (RDA) for energy. Maternal age, educational level, gestational age at enrolment, and pregnancy Body Mass Index (BMI) were significantly associated with inadequacy of nutrients intake. The study showed that only $41.9 \%$ of the respondents met the Recommended Dietary Allowance (RDA) for energy, while more than $5 \%$ had normal Body Mass Index (BMI).
\end{abstract}

KEYWORDS: Nutrients, Pregnant, Dietary, Prevalence, Women.

\section{INTRODUCTION}

Healthy eating is important at all stages of life, especially during pregnancy. However, the choices of what to eat and drink during pregnancy can affect the health of the mother and the health of the baby for many years to come. Nutrient intake is important to the wellbeing of pregnant women and the fetus. Inadequate of nutrient intake can lead to maternal anaemia, increasing the risk for other maternal morbidities and mortality, fetal growth retardation and low fetal birth weight (Sukchan et al., 2010), and Brabin et al., (2001).

However, pregnant mothers do not need more of certain nutrients so it is very important they make good choices for a nutritious diet (Oleyede, 2010). Dietary guidelines have been set by a variety of private and Government organizations. These guidelines are designed to reduce the risk of developing certain diseases. One of these regulating bodies is Food and Nutrition Board of the Nation Academy of Services, United States of America (USA) Recommended intakes of nutrients that met the need of almost all healthy people of similar age and gender. The Recommended Dietary Allowance (RDA) has become the premier nutrient standard in the United States of America (US) and the world (Olawale, 2008). The daily food group requirements during pregnancy are outlined in the table 1.The numbers in the middle column serve as guide as to how many serves to eat from each food group per day. One serve is equal to each of the foods in the column on the right. For example, one serve of bread and porridge (corn flakes) is equal to half cup of rice.

The pregnant women in General Hospital Calabar, just like other pregnant women in the World need healthy food and are to avoid nutrients inadequacy.

Grace Michael Inah, Department of Hospitality and Tourism, Faculty of Management Sciences, Cross River University of Technology, Calabar, Nigeria.

Mary Iyam, Department of Public Health, Allied Medical College, University of Calabar, Calabar, Nigeria.

Mgban, Emilia, Home Economics Department, Federal College of Education, Obudu, Cross River State, Nigeria. 
TABLE 1: DAILY FOOD GROUP REQUIREMENT DURING PREGNANCY.

\begin{tabular}{|c|c|c|}
\hline Food Group & Number of serves & 1 serve \\
\hline Breads, Cereals, Rice, Pasta, Noodles & $8-12$ & $\begin{array}{l}1 \text { slice bread } \\
1 / 2 \text { medium bread roll } \\
1 / 2 \text { cup cooked rice, pasta, } \\
\text { noodles } \\
1 / 2 \text { cup breakfast cereal flakes } \\
1 / 4 \text { cup muesli or oats }\end{array}$ \\
\hline Fruit & 4 & $\begin{array}{l}1 \text { piece medium sized fruit } \\
2 \text { pieces smaller fruit } \\
20 \text { grapes or cherries } \\
1 / 2 \text { cup juice } \\
1 \text { cup diced/canned fruit } \\
11 / 2 \text { tbsp sultanas } \\
\end{array}$ \\
\hline Vegetables, Legumes & $5-6$ & $\begin{array}{l}1 \text { medium potato/yam } \\
1 / 2 \text { medium sweet potato } \\
1 \text { cup lettuce or salad vegies } \\
1 / 2 \text { cup cooked vegetables }\end{array}$ \\
\hline Meat, fish, poultry, eggs, nuts, legumes & $11 / 2$ & $\begin{array}{l}65-100 \mathrm{~g} \text { cooked } \\
\text { meat/chicken } \\
80-120 \mathrm{~g} \text { cooked fish } \\
2 \text { small eggs } \\
1 / 3 \text { cup cooked beans, } \\
\text { lentils, chick peas, split peas } \\
\text { or canned beans } \\
1 / 3 \text { cup peanuts/almonds } \\
\end{array}$ \\
\hline Milk, yogurt, cheese & 2 & $\begin{array}{l}1 \text { cup milk } \\
40 \mathrm{~g} \text { ( } 2 \text { slices) cheese } \\
200 \mathrm{~g} \text { yoghurt } \\
1 \text { cup custard }\end{array}$ \\
\hline Extra Foods & $0-2 \frac{1}{2}$ & $\begin{array}{l}3-4 \text { sweet biscuits } \\
30 \mathrm{~g} \text { potato crisps } \\
2 \text { scoops ice-cream } \\
1 \quad \text { tbsp }(20 \mathrm{~g}) \\
\text { margarine, oil } \\
\end{array}$ \\
\hline
\end{tabular}

Ministry of Health, (2006).

\section{RECOMMENDED NUTRITIONAL INTAKE FOR PREGNANT MOTHERS}

\section{Vitamins B6 and B12}

The American Congress of Obstetricians and Gynecologists recommends $1.9 \mathrm{mg}$ of vitamin B6 and 2.6 $\mathrm{mg}$ of vitamin B12 as part of prenatal diet for pregnant mothers. B6 is needed for the formation of red blood cells needed by the pregnant mothers and the baby. Foods rich in vitamin B6 include fish, beef and poultry. Fruits and vegetable sources of this vitamin include potatoes, spinach, banana and avocado. In addition to helping to form red blood cells, vitamin B12 also aids in the functioning of the central nervous system. This vitamin is found in eggs, dairy products and poultry.

\section{Vitamins A, C and D}

Pregnant mothers need seven hundred and seventy (770) micrograms of vitamin A and eighty five (85) micrograms (mg) of vitamin $C$ per day during pregnancy. Vitamin A is required for healthy skin and eyesight and is found in carrots, green leafy vegetables and sweet potatoes. The baby needs vitamin $\mathrm{C}$ for healthy teeth, gums and bones and this vitamin is found in tomatoes, citrus fruits, cabbage and broccoli. Vitamin $D$ is needed for the formation of baby's teeth and bones. The recommended dietary allowance of vitamin D is two hundred (200) International Units and is found in milk, salmon, sardines and egg yolk.

\section{Iron and Protein}

Iron is necessary for the formation of red blood cells in both the mother and the fetus. The recommended dietary allowance of iron is twenty seven (27) micrograms (mg) during pregnancy. Iron-rich foods include, beef, poultry, pulses, dried fruit and green vegetables. These foods are also an excellent source of protein, which is needed for the growth and development of the baby. The American Pregnancy Association recommends seventy five to one hundred (75 to 100) grammes (g) of protein per day. 


\section{Folic Acid and Calcium}

Pregnant mothers need more folic acid to prevent the baby developing spinal bifida, a neural tube defect. It also aids in the production of proteins and enzymes needed by both the mother and the baby. For pregnant mothers, the recommended daily allowance of folic acid is six hundred (600) micrograms. Dietary sources of folic acid include beans, lentils, fresh green vegetables, oranges and poultry. Calcium is needed for strong bones and teeth of both the mother and the developing fetus. Pregnant women require one thousand $(1,000)$ micrograms $(\mathrm{mg})$ of calcium per day when they consume three to four servings of pasteurized milk, yoghurt and cheese per day.

Table 2: Recommended Nutrient intake for pregnant women

\begin{tabular}{|l|l|}
\hline Food groups & Requirement per day \\
\hline Vitamin B6 & $1.9 \mathrm{mg}$ \\
Vitamin B12 & $2.6 \mathrm{mg}$ \\
Vitamin A & $770 \mathrm{mg}$ \\
Vitamin C & $85 \mathrm{mg}$ \\
Vitamin D & $200 \mathrm{IU}$ \\
Iron & $27 \mathrm{mg}$ \\
Protein & $75-100 \mathrm{mg}$ \\
Folic Acid & $600 \mathrm{mg}$ \\
Calcium & $1000 \mathrm{mg}$ \\
Energy & $350-450$ Kcal more than pre-pregnant \\
\hline
\end{tabular}

Source: American Congress of Obstetricians and Gynecologists (ACOG)

An average pregnant woman has an estimated energy requirement of approximately three hundred and fifty to four hundred and fifty (350 to 450 ) kcal greater than pre-pregnancy needs during the second and third trimester. The vitamin and mineral need increased by $50 \%$ during pregnancy, whereas energy need during the second and third trimester represent only a $20 \%$ increase, based on adding four hundred (400) kcal to the intake of two thousand (2000) kcal per day by none pregnant women.

The Recommended Dietary Allowance (RDA) for protein increases by twenty five (25) grammes (g) daily or alternatively to $1.1 \mathrm{~g} / \mathrm{kg}$ body weight. The Recommended Dietary Allowance for carbohydrate increases to one hundred and seventy five (175) grammes (g) daily. This amount prevents Ketosis, which can harm the fetus. (Oleyede, 2010)

\section{The objective of the study}

The study was investigating nutrient intake of pregnant women in relation to their Body Mass Index among pregnant women who attended ante-natal clinic in General Hospital Calabar, Cross River State, Nigeria and to assess the factors associated with nutrient inadequacy.

\section{Specific objectives}

The specific objectives were to;

-assess nutrients intake of pregnant women in General Hospital, Calabar.

-assess their nutritional status from the Body Mass Index -determine food preferred among pregnant women and their nutrient inadequacy.

\section{Study area}

The study was carried out in the out- patient Department of General Hospital Calabar, Cross River State, Nigeria. The subjects used were all registered pregnant women.

Study design

A hospital-based survey was approved by the Department of Biochemistry (Nutrition and Food Science) and permission was obtained from the chief Medical Director of General Hospital Calabar and the Nurses that were on duty that day. Verbal consent was obtained from all registered pregnant women for that day.

\section{Material and methods:}

After receiving a full explanation on the purpose of the study, the women were given a self administered structured questionnaire to ascertain their individual dietary history and bio-data. Table 1, of food intake recommended for pregnant women, were used as guideline of food items required. The food groups including rice, vegetable, meat, fruits, yam, fat, and milk were listed. The units for measuring the amount of each food was recorded as follow: ladle and table spoon for rice and vegetables, portions and pieces for fruits and meat, teaspoon (tsp) for fat, and glasses for milk and water. Photographs of the types and amount of foods were shown to the women to improve estimation of portion size. The subjects were requested to recall their average daily food intake for breakfast, lunch, dinner and supper over the previous day for all food groups and amount eaten using the standard units mentioned above. If the consumed food was not in the list, then that kind of food was converted into an equivalent amount of the same food type. 


\section{Statistical analysis}

The total daily intake of nutrients was described using means and Standard Deviation (SDs). The data obtained from the 24-hour dietary recall, from the food frequency questionnaire and their socio-economic characteristics were analyzed using the SPSS version 11.

Nutrient variable: The main variables were level of nutrients intake and Body Mass Index.

Independent variables: Individual characteristics obtained from each subject were age, religion, gestation age, occupation, educational level, pre- pregnancy weight and height, and unmarried status.

The methods employed in assessing the nutritional status were: Anthropometric measurements as recommended by WHO (1995), and food models along with a Structured Questionnaire covering individual factors like economic factors and a 24-hour dietary recall methods were used.

Food composition table was also used with an accurate description of the kind and amount of food eaten and amount of nutrients present in the diet (Oguntona and Akinyele, 2002).

The nutrients in the food consumed by the pregnant women in General Hospital Calabar were determined using the food composition table. The analyzed nutrients were compared with a reference standard (RDA) Table 1 and Body Mass Index (BMI) of $24.9 \mathrm{~kg} / \mathrm{m} 2$.

\section{RESULTS}

The information collected from the 24-hour dietary recall was used to justify the first specific objective raised. The information from the Anthropometric assessment was used to justify the second objective while the Demographic data was used to justify the third specific objective of this study.

Table 3, shows distribution of the following factors; Pregnant women by their Age, Occupation, religion, Educational achieve, gestational age during registration, Body Mass Index and other factors. The respondents who were less than 20 years were $2.7 \%, 60.7 \%$ falls between the ranges of 20 to 30 years, $34 \%$ of the respondents fall between the ages of 31 to 40 years, while $2.0 \%$ of the pregnant women fall between 41 to 50years. The respondents who were Christians were $63.3 \%$, while $36.7 \%$ were Muslims, $2.7 \%$ of the respondents were single, while $96.7 \%$ were married. The respondents who had vocational training were $2.7 \%, 20.7 \%$ of them were artisan, $34.7 \%$ of the pregnant women were civil servants, then $2.0 \%$ were farmers, and $0.9 \%$ of the respondents were private employees, while $4.0 \%$ were students, $31.3 \%$ of this women were traders while $60 \%$ were unemployed. The respondents' educational achievements were recorded as follows: $2.2 \%$ have no educational background, $16.0 \%$ have primary education and $31.3 \%$ of these respondents have secondary education while $48.0 \%$ of the pregnant women have tertiary education. The table 3 shows the gestational age of the respondents to be $1.3 \%$ at their first trimester, $20 \%$ were in their second trimester, $78.7 \%$ were at their third trimester. The Body Mass Index (BMI) category of the respondents were as follows: $3.3 \%$ of the respondent has BMI of $<19.8 \mathrm{~kg} / \mathrm{m}^{2}$ (low), $55.3 \%$ had a BMI of $25 \mathrm{mkg} / \mathrm{m}^{2}$ (normal), while $41.3 \%$ of them had a BMl of $27 \mathrm{~kg} / \mathrm{m}^{2}$ (high).

TABLE 3: Respondents' age, occupation, Religion, Education status, BMI

\begin{tabular}{|l|l|l|l|}
\hline Factor & Freq. & $\%$ & Cum\% \\
\hline Age (years) & & & \\
\hline 20 & 4 & 2.7 & 2.2 \\
$31-40$ & 91 & 60.7 & 63.3 \\
$41-50$ & 52 & 34.7 & 98.0 \\
Total & 3 & 2.0 & 100.0 \\
\hline Occupation & 150 & 100.0 & \\
\hline Artisan & & & \\
Civil servant & 31 & 20.7 & 21.3 \\
Farmers & 52 & 34.7 & 56.0 \\
Private employed & 3 & 2.0 & 58.0 \\
Student & 1 & 0.7 & 58.7 \\
Traders & 6 & 4.0 & 62.7 \\
Unemployed & 47 & 31.3 & 94.0 \\
Total & 9 & 6.0 & 100.0 \\
\hline Religion & 150 & 100.0 & \\
\hline Christianity & & & \\
Islam & 95 & 63.3 & 63.3 \\
Total & 55 & 36.7 & 100.0 \\
\hline Education achieved & 150 & 100.0 & \\
No formal education & 3 & 2.0 & 2.0 \\
Primary education & 24 & 16.0 & 18.0 \\
Secondary education & 47 & 31.3 & 49.0 \\
Tertiary education & 72 & 48.0 & 97.3 \\
\hline
\end{tabular}




\begin{tabular}{|l|l|l|l|}
\hline Vocational education & 4 & 2.7 & 100.0 \\
Total & 150 & 100.0 & \\
\hline Gestational age at enrolment & & & \\
$1^{\text {st }}$ Trimester (0-14 wks) & 2 & 1.3 & 1.3 \\
$2^{\text {nd }}$ Trimester (15-24 wks) & 30 & 20.0 & 21.3 \\
$3^{\text {rd }}$ Trimester (25-37 wks) & 118 & 78.7 & 100 \\
Total & 150 & 100.0 & \\
\hline Body mass index (kg/m2) & & & \\
Under weight (<19.8) & 5 & 3.3 & 3.3 \\
Normal (25) & 83 & 55.3 & 58.7 \\
Over weight (27) & 62 & 41.3 & 100.0 \\
Total & 150 & 100.0 & \\
\hline
\end{tabular}

Table 4 shows the respondents' intake of fruits and vegetables, drinks, snacks, meal skipping and consumption pattern per day. The number of respondents who did not consume fruits were $0.9 \%, 8 \%$ consumed orange only, $79.6 \%$ of the respondents consumed orange and any other fruit, $5.3 \%$ apple only, $9.4 \%$ of the respondent consumed apple and any other fruit, $1.35 \%$ pineapple only, $1.3 \%$ consumed water melon only, $1.4 \%$ took water melon and any other fruit, $0.7 \%$ consumed sugar cane, $0.7 \%$ consumed paw-paw and banana, $1.3 \%$ do not consumed any of the fruits while, $98 \%$ consumed vegetables. The drinks, snacks and meal skipping of the respondents were as follows: $33.0 \%$ did not consume any drinks, $19.3 \%$ consumed coke only, $41.3 \%$ drank coke and any other drink, 6.0\% consumed Pepsi only, 6.7\% had Pepsi and any other drink, 4.0\% consumed 5-alive, $6.7 \%$ consumed 5 -alive and any other drink, $1.3 \%$ had Sorrel (zobo drink) only, 1.3\% took yoghurt only, $2.0 \%$ Lacasera only, $2.0 \%$ malt only, $1.3 \%$ milk only, $0.7 \%$ consumed Viju milk. 5.3\% did not take snacks, $8.7 \%$ consumed puff-puff, $40.7 \%$ took puff-puff and any other snack, $4.0 \%$ took chin-chin, $10.0 \%$ chin-chin and any other snack, $2.0 \%$ biscuits, $4.0 \%$ cake and any other snack, $1.3 \%$ ate plantain chips, $3.3 \%$ ate dough-nut and meat pie, $12.0 \%$ meat pie only, $2.0 \%$ meat pie and egg roll, $1.4 \%$ groundnut, $0.7 \%$ scones. $46.7 \%$ of the respondents did not skip meals, 9.3\% skipped breakfast, $29.3 \%$ skipped lunch, $2.0 \%$ skipped lunch and dinner, $1.3 \%$ skipped dinner while $1.4 \%$ skipped the whole meal. The source and respondents' pattern of food consumed and consumption pattern of in- between meals per day were as follows: $80.7 \%$ of the respondents consumed home-made food, $3.3 \%$ of the respondents purchase their food, while $16.0 \%$ of the women consumed both foods. The respondents' consumption pattern per day were as follows: $2.0 \%$ of respondents ate once a day, $18.7 \%$ ate twice aday,38.0\%ate thrice aday, $26.0 \%$ had their meals four times a day, $6.6 \%$ ate five times per day, $14.7 \%$ respondents had their meals six times per day,and $4.0 \%$ ate seven times per day.

Table 4: Respondents' intake of fruits, vegetables, snacks, skipping meal

\begin{tabular}{|l|l|l|l|}
\hline & $\mathrm{F}$ & $\%$ & Cum. \% \\
\hline Fruits & & & \\
\hline None & 1 & 0.7 & 0.7 \\
Orange & 12 & 8.0 & 8.7 \\
Orange/any other & 107 & 71.3 & 80.0 \\
Apple & 8 & 5.3 & 85.3 \\
Apple/any other & 14 & 9.4 & 94.7 \\
Pineapple & 2 & 1.3 & 96.0. \\
Water melon & 2 & 1.3 & 97.3 \\
Water melon/any other fruit & 2 & 1.3 & 98.7 \\
Sugar cane & 1 & 0.7 & 99.3 \\
Paw- paw and banana & 1 & 0.7 & 99.3 \\
Total & 150 & 100.0 & 100.0 \\
Vegetables & & & \\
None consumption of vegetables & 2 & 1.3 & 1.3 \\
Consume various types of vegetables & 148 & 98.7 & 100.0 \\
Total & 150 & 100.0 & \\
\hline Drinks & & & \\
No consumption of any drink & 5 & 3.3 & 3.3 \\
Consumed: coke & 29 & 19.3 & 22.7 \\
Coke and any other drinks & 62 & 41.3 & 64.0 \\
\hline
\end{tabular}




\begin{tabular}{|c|c|c|c|}
\hline $\begin{array}{l}\text { Pepsi drink } \\
\text { Pepsi and any other drinks } \\
\text { 5-Alive drink } \\
\text { 5- Alive and any other drink } \\
\text { Chi-vita } \\
\text { Yoghurt } \\
\text { Lacasera drink } \\
\text { Malt drink } \\
\text { Milk } \\
\text { Viju milk } \\
\text { Total }\end{array}$ & $\begin{array}{l}9 \\
10 \\
6 \\
10 \\
2 \\
8 \\
3 \\
3 \\
2 \\
1 \\
150\end{array}$ & $\begin{array}{l}6.0 \\
6.7 \\
4.0 \\
6.7 \\
1.3 \\
5.3 \\
2.0 \\
2.0 \\
1.3 \\
0.7 \\
100.0\end{array}$ & $\begin{array}{l}70.0 \\
76.7 \\
80.7 \\
87.4 \\
88.7 \\
94.0 \\
96.0 \\
98.0 \\
99.3 \\
100.0\end{array}$ \\
\hline $\begin{array}{l}\text { Snacks } \\
\text { Consume no snacks } \\
\text { Consumes: puff-puff } \\
\text { puff-puff and any other snack } \\
\text { Chin- Chin } \\
\text { Chin- chin and any other snack } \\
\text { Biscuits } \\
\text { Cake and any other snack } \\
\text { Plantain chips } \\
\text { Doughnut } \\
\text { Fish and meat pie } \\
\text { Egg roll } \\
\text { Groundnut } \\
\text { Scones } \\
\text { Pan-cake } \\
\text { Total }\end{array}$ & $\begin{array}{l}8 \\
13 \\
61 \\
6 \\
16 \\
3 \\
6 \\
2 \\
5 \\
6 \\
18 \\
3 \\
2 \\
1 \\
150\end{array}$ & $\begin{array}{l}5.3 \\
8.7 \\
40.7 \\
4.0 \\
10.7 \\
2.0 \\
4.0 \\
1.3 \\
3.3 \\
4.0 \\
12 .- \\
2.0 \\
1.3 \\
0.7 \\
100.0\end{array}$ & $\begin{array}{l}5.3 \\
14.0 \\
54.7 \\
58.7 \\
69.3 \\
71.0 \\
75.3 \\
76.7 \\
80.0 \\
84.0 \\
96.0 \\
98.0 \\
99.3 \\
100.0\end{array}$ \\
\hline $\begin{array}{l}\text { Food consumption by respondents per day } \\
\text { Food groups } \\
\text { Cereals } \\
\text { Roots and tubers } \\
\text { Legumes } \\
\text { Vegetables } \\
\text { Dairy products } \\
\text { Fish/Egg } \\
\text { Fruits } \\
\text { Snacks } \\
\text { Drinks } \\
\text { Total }\end{array}$ & & $\begin{array}{l}23.5 \\
11.9 \\
6.5 \\
13.5 \\
12.9 \\
14.1 \\
5.6 \\
9.5 \\
2.5 \\
100.0\end{array}$ & $\begin{array}{l}23.5 \\
35.4 \\
41.9 \\
55.4 \\
68.3 \\
82.4 \\
88.0 \\
97.5 \\
100.0\end{array}$ \\
\hline $\begin{array}{l}\text { Skipping of meals by respondents } \\
\text { No skipping of meals } \\
\text { Skipping of: Breakfast } \\
\text { Lunch } \\
\text { Lunch and dinner } \\
\text { Dinner only } \\
\text { The whole meal } \\
\text { Total }\end{array}$ & $\begin{array}{l}70 \\
11 \\
44 \\
3 \\
20 \\
2 \\
150\end{array}$ & $\begin{array}{l}46.7 \\
7.3 \\
29.3 \\
2.0 \\
13.3 \\
1.3 \\
100.0\end{array}$ & $\begin{array}{l}46.7 \\
54.0 \\
83.0 \\
85.3 \\
98.6 \\
100.0\end{array}$ \\
\hline $\begin{array}{l}\text { Food consumption preference of respondents } \\
\text { Food preferred } \\
\text { None } \\
\text { Pounded yam } \\
\text { Liked any food } \\
\text { Beans } \\
\text { Bread } \\
\text { Eba } \\
\text { Fruits } \\
\text { Corn flakes } \\
\text { Plantain } \\
\text { Rice } \\
\text { Sermovita } \\
\text { Snacks }\end{array}$ & $\begin{array}{l}17 \\
17 \\
3 \\
14 \\
1 \\
6 \\
4 \\
3 \\
3 \\
66 \\
1 \\
3\end{array}$ & $\begin{array}{l}11.3 \\
11.3 \\
2.0 \\
9.3 \\
0.7 \\
4.0 \\
2.7 \\
2.0 \\
2.0 \\
44.0 \\
0.7 \\
2.0\end{array}$ & $\begin{array}{l}11.3 \\
2.6 \\
24.6 \\
33.9 \\
34.6 \\
38.6 \\
41.3 \\
43.3 \\
45.3 \\
89.3 \\
90.0 \\
92.0\end{array}$ \\
\hline
\end{tabular}




\begin{tabular}{|c|c|c|c|}
\hline $\begin{array}{l}\text { Tuwo } \\
\text { Vegetables } \\
\text { Wheat } \\
\text { Fufu (fermented cassava) } \\
\text { Total }\end{array}$ & $\begin{array}{l}1 \\
4 \\
2 \\
5 \\
150\end{array}$ & $\begin{array}{l}0.7 \\
2.7 \\
1.3 \\
3.3 \\
100.0\end{array}$ & $\begin{array}{l}92.7 \\
95.4 \\
96.7 \\
100.0\end{array}$ \\
\hline $\begin{array}{l}\text { Patterns of food consumption per day } \\
1 \\
2 \\
3 \\
4 \\
5 \\
6 \\
7 \\
\text { Total }\end{array}$ & $\begin{array}{l}3 \\
28 \\
57 \\
39 \\
10 \\
7 \\
6 \\
150\end{array}$ & $\begin{array}{l}2.0 \\
18.7 \\
38.0 \\
26.0 \\
6.6 \\
4.7 \\
4.0 \\
100.0\end{array}$ & $\begin{array}{l}2.0 \\
20.7 \\
58.7 \\
84.7 \\
91.3 \\
96.0 \\
100.0\end{array}$ \\
\hline $\begin{array}{l}\text { Food consumption preference of respondents } \\
\text { Food preferred } \\
\text { None } \\
\text { Pounded yam } \\
\text { Like any food } \\
\text { Beans } \\
\text { Bread } \\
\text { Eba } \\
\text { Fruits } \\
\text { Pap } \\
\text { Plantain } \\
\text { Rice } \\
\text { Sermovita } \\
\text { Snacks } \\
\text { Tuwo } \\
\text { Vegetables } \\
\text { Wheat } \\
\text { Yam } \\
\text { Total }\end{array}$ & $\begin{array}{l}17 \\
17 \\
3 \\
14 \\
1 \\
6 \\
4 \\
3 \\
3 \\
66 \\
1 \\
3 \\
1 \\
4 \\
2 \\
5 \\
150\end{array}$ & $\begin{array}{l}11.3 \\
11.3 \\
2.0 \\
9.3 \\
0.7 \\
4.0 \\
2.7 \\
2.0 \\
2.0 \\
44.0 \\
0.7 \\
2.0 \\
0.7 \\
2.7 \\
1.3 \\
3.3 \\
100.0\end{array}$ & $\begin{array}{l}11.3 \\
2.6 \\
24.6 \\
33.9 \\
34.6 \\
38.6 \\
41.3 \\
43.3 \\
45.3 \\
89.3 \\
90.0 \\
92.0 \\
92.7 \\
95.4 \\
96.7 \\
100.0\end{array}$ \\
\hline
\end{tabular}

TABLE 5: Mean and standard deviation of Nutrient intake of Respondents

\begin{tabular}{|l|l|l|}
\hline Nutrient intake & Mean \pm /standard deviation & \% RDA \\
\hline Energy $(\mathrm{kcal})$ & $1048 \pm 1732.7$ & 41.9 \\
\hline Carbohydrates $(\mathrm{g})$ & $170.1 \pm 2971.1$ & 97.1 \\
\hline Protein $(\mathrm{g})$ & $29.32 \pm 50.3$ & 39.1 \\
\hline Calcium $(\mathrm{mg})$ & $392.9 \pm 764.4$ & 39.3 \\
\hline Ferrous $(\mathrm{mg})$ & $29.1 \pm 73.5$ & 107.8 \\
\hline Folic acid $(\mathrm{mg})$ & $33.34 \pm 71.1$ & 5.6 \\
\hline Vitamin C $(\mathrm{mg})$ & $23.6 \pm 55.0$ & 27.8 \\
\hline
\end{tabular}

\section{DISCUSSION}

The findings of the present study showed that, the age of the pregnant women, their occupation, religion, education achieved, gestation age at enrolment, and their body mass index (BMI) affects the respondents' intake of fruits and vegetables, snacks and drinks, skipping of meals per day and nutrient inadequacy of the pregnant women who registered at the out-patient department of General hospital, Calabar Nigeria.

(Kesa et al., 2005) found out that Education has a consistent effect on nutrient intake and inadequacy of almost all nutrients. Women who had a primary education or less were more likely to have nutrient inadequacy. It is also possible that women with a higher education have better food habits than those with a low education. This is supported by a study in Bangladesh which found that higher education which brings higher income is associated with higher intake of protein, fatty acid, dietary fiber, cholesterol, potassium, calcium, magnesium, iron, vitamin A, D, E and C and folic acid (Islam et al.,2004). In addition, gestational age at enrolment of 14 weeks or more was found to be associated with a lower risk for inadequacy of both macronutrients and micronutrients 
(Islam et al., 2004). The factors mentioned above were associated with nutrient intake and nutrient inadequacy of pregnant mothers in General Hospital, Calabar Cross River State, Nigeria.

\section{CONCLUSION}

The nutrients intake of pregnant women surveyed in this work were low compare with the Recommended Dietary Allowance (RDA) required. The number of respondents with normal Body Mass Index (BMI) was high compare with low and high Body Mass Index (BMI) of the respondents. The pregnant women consumed more of cereal foods than any other food group. The respondents who feed on rice always were many, as seen in table 3 above. The socio-economic factors also affected the type, choice and frequency of food consumed thereby causing nutrients inadequacy.

\section{RECOMMENDATION}

Based on the findings of the study, the following recommendations are hereby made:

1. Pregnant women in out-patient department of General Hospital should pay more attention to healthy eating since this will improve their health and that of the fetus.

2. Adequate counseling should be provided during Ante-natal clinic on adequate and quality nutrient intake during pregnancy.

3. They should consume nourishing meals that contain protein, fats, vitamins and minerals as well as little carbohydrate, taking into consideration their nutritive value.

4. They should include sea foods like mussels, fresh crayfish, periwinkles and small fish (Ekpai) in their meals.

5. The Government should emphasize more on nutrition education, programs and policies that will help in the consumption of food and nutrients that will build pregnant women and the fetus' health.

6. Job opportunities should be created for low income earners and others to enable them feed and sustain their families and provide adequate diet for pregnant women.

\section{REFERENCES}

Brabin, B. J., Hakimi, M and Pelletier, D., 2001. An analysis of anaemia and pregnancy related maternal mortality. J Nutr (131): 604S-615S.

Gaylezomila., 2011. American Congress of Obtetricians and Gynecologists. Reviewed,Jan. 2011.

Islam, M. Z., Akhtaruzzaman, M and Lamberg-Allardt, C., 2004. Nutritional status of women in Bangladesh: comparison of energy intake and nutritional status of a low income rural group with a high income urban group. Asia Pacific J Clin Nutr (13): 61-68.
Kate Trillin., 2010. Healthy eating during Pregnancy. A Report series. Willington: Ministry of Health.

Kesa, $\mathrm{H}$ and Oldewage, T. W., 2005. Anthropometrics Indications nd nutritional intake of women in the Vaal Triangle, South Africa. Public Health. (119): 249-300.

Kesa, $\mathrm{H}$ and Oldewage-Theron, W., 2005. Anthropometric indications and nutritional intake of women in the Vaal Triangle, South Africa. Public Health (119): 294-300.

Murakami, K., Miyake, Y., Sasaki, S., Tanaka, K., Ohya, Y and Hirota, Y., 2009. The Osaka Maternal and Child Health Study Group: Education, but not occupation or household income, is positively related to favorable dietary intake patterns in pregnant Japanese women: the Osaka Maternal and Child Health Study. Nutr Res (29): 164-172.

Nutrition Division Department of Health, Ministry of Public Health: Nutrition values of Thai foods Bangkok: Ministry of Public Health 1992.

Oguntona, C and Akinyele, I., 2002. Food and Nutrient intake by Nigerian Adolescents during the third trimester. Nutrition, 2002, (18): 673-697.

Olawale, F. A., 2008. Dietary guidelines for good Health. Wilolud Online Journals Continental J. Medical Research (2): 24-27.

Oleyede, O. A., 2010. Nutrient intake and Body Mass Index of pregnant women attending Ante natal Clinic of State Hospital, ljaiye, Abeokuta, Ogun State. $2007 / 0283$.

Piammongkol, S., Marks, G. C., Williams, G and Chongsuvivatwong, V., 2004. Food and nutrient consumption patterns in third trimester ThaiMuslim pregnant women in rural southern Thailand. Asia Pac J Clin Nutr 13:236-241.

Sukcham, P., Liabsuetrakul, T., Chongsuvivatwong, V., Songwathana, P., Somstrivichal, V and Kuning, M., 2010, Inadequacy of nutrient intake among pregnant women in the deep South of Thailand. BMC Public Health, (10): 572.

WHO., 1995. World Health Organization, Physical status: The use and interpretation of Anthropometrics. Technical Report Series: 854. Geneva. 